\title{
BIO-XYZ, What is XYZ?
}

\author{
Subir Kumar Nandy* \\ Department of Systems Biology, Technical University of Denmark, Denmark
}

Submission: March 04, 2017; Published: April 20, 2017

"Corresponding author: Subir Kumar Nandy, Department of Systems Biology, Technical University of Denmark, Denmark, Tel: +45 81499898; Email: skna@bio.dtu.dk

\begin{abstract}
Bio is a term that can be added to several different features to make different subjects based on facts; species etc. and all those subjects are interconnected in between. When we are talking about trees or animals or cells or genes or DNA or RNA, in all cases, the term bio is very common to use. One may use biology as a general term or may be bioscience or may be bio-XYZ. Therefore, bio-XYZ can be the most general term one can use to define a subject in bio division. Our life and work environment and everyday life connected to fascinating and very complex world with a lot of bio subdivisions where all biological themes are connected somehow.
\end{abstract}

Keywords: Bioscience; Biomedical engineering

\section{Discussion}

Now the question is what is bioscience exactly? Bio and science makes bioscience and that means it should include all scientific divisions under bio where XYZ is science. We can see the divisions under bioscience in the following table where the main divisions are stated. Comparing all the divisions, it is also true that some of this also fits under other divisions. For example, bioinformatics can fit under biomedical engineering too. Therefore, all of these are interconnected. As the journal is looking for biomedical engineering use and application too, therefore, it is always need to know what else can be suited under this division. Basically, biomedical engineering is application of traditional engineering principles and design procedures to analyze and solve problems in biology and medicine. Biomedical engineering has some sub disciplines and those are for example like bioinstrumentation, biomechanics, biomaterials, bio-signal processing, tissue engineering, imaging, neural systems and engineering, robotics etc. where a lot of designing instruments are included and also software and devices are well covered which bring together knowledge from many technical sources to develop novel procedures for future generations and also conducting research needed to solve many issues to solve various clinical problems (Table 1 ).
Table 1: Bioscience.

\begin{tabular}{|c|c|}
\hline \multicolumn{2}{|c|}{ Bioscience Subjects } \\
\hline 1. Botany & 2. Zoology \\
\hline 3. Genetics biology or Genetics & 4. Biomedical engineering \\
\hline 5. Microbiology & 6. Forensic bioscience \\
\hline 7. Biotechnology & 8. Animal biotechnology \\
\hline 9. Biochemistry & 10. Agricultural biology \\
\hline 11. Bioethics & 12. Ecology \\
\hline 13. Biophysics & 14. Food biology or Food science \\
\hline 15. Bioinformatics & 16. Cell biology \\
\hline 17. Biodiversity & 18. Immunology \\
\hline 19. Food and Feed science & 20. Molecular biology \\
\hline
\end{tabular}

\section{Conclusion}

This small paper or commentary is a suggestion to the scientific community that all subjects under bio based division can be inter related and therefore bio-XYZ is much more interdisciplinary subjects where the gap between engineering and other division such as design, medicine, science and problem solving skills may joined together and solve the advanced health care treatment for better cure and control over diseases. 
(C) This work is licensed under Creative BY DOI: $10.19080 /$ CTBEB.2017.03.555606

\section{Your next submission with Juniper Publishers} will reach you the below assets

- Quality Editorial service

- Swift Peer Review

- Reprints availability

- E-prints Service

- Manuscript Podcast for convenient understanding

- Global attainment for your research

- Manuscript accessibility in different formats

( Pdf, E-pub, Full Text, Audio)

- Unceasing customer service

Track the below URL for one-step submission

https://juniperpublishers.com/online-submission.php 